\title{
Population parameters of the endangered titi monkey, Callicebus coimbrai Kobayashi and Langguth, 1999, in the fragmented landscape of southern Sergipe, Brazil
}

\author{
Chagas, RRD. ${ }^{a *}$ and Ferrari, $S F .^{b}$ \\ aPrograma de Pós-graduação em Desenvolvimento e Meio Ambiente, Universidade Federal de Sergipe - UFS, \\ Av. Marechal Rondon, s/n, Jardim Rosa Elze, CEP 49100-000, São Cristóvão, SE, Brazil \\ ${ }^{b}$ Departamento de Biologia, Universidade Federal de Sergipe - UFS, \\ Av. Marechal Rondon, s/n, Jardim Rosa Elze, CEP 49100-000, São Cristóvão, SE, Brazil \\ *e-mail: renata_deda118@hotmail.com
}

Received May 13, 2010 - Accepted August 13, 2010 - Distributed August 31, 2011

(With 1 figure)

\begin{abstract}
The recently-discovered titi, Callicebus coimbrai, is endemic to the coastal Brazilian Atlantic Forest south of the São Francisco River, a region with a long tradition of deforestation. While a number of $C$. coimbrai populations have now been identified, little is known about basic population parameters. Considering the importance of this information for conservation planning, the population of a site in southern Sergipe (with a total area of forest of approximately $500 \mathrm{ha}$ ) was surveyed between April and October 2008. Standard line transect procedures were used in the four largest fragments, and additional monitoring included the use of playback broadcasts for the observation of titi groups. The presence of titis was confirmed in all the forest fragments at the site, including one of only five hectares. Two other primates Callithrix jacchus and Cebus xanthosternos - were also recorded at the site, but were less abundant than titis. A total transect walk of $476 \mathrm{~km}$ provided 164 sightings of primates, the majority of which (104) were of Callicebus coimbrai. Titi groups ranged in size between two and five individuals. The most reliable estimate of overall population density, derived from the combined data set, was 12.6 individuals per $\mathrm{km}^{2}$, although density was much higher in smaller (more disturbed) fragments. The total population of Callicebus coimbrai at the site was estimated to be at least 50 individuals, which may represent a considerable proportion of the population of the species remaining in the wild. In addition to its apparent tolerance of habitat fragmentation, densities of C. coimbrai recorded at the site compare favourably with those of other Atlantic Forest titi species.
\end{abstract}

Keywords: Callicebus coimbrai, Brazilian Atlantic Forest, habitat fragmentation, population density, conservation.

\section{Parâmetros populacionais do guigó ameaçado, Callicebus coimbrai Kobayashi and Langguth, 1999, na paisagem fragmentada do sul de Sergipe, Brasil}

\begin{abstract}
Resumo
O guigó-de-Coimbra-Filho recém descoberto, Callicebus coimbrai, é endêmico da Mata Atlântica do litoral brasileiro ao sul do rio São Francisco, uma região marcada pelo desmatamento. Enquanto um número de populações de C. coimbrai já foram identificadas, pouco se sabe sobre os parâmetros populacionais básicos. Considerando a importância dessas informações para o planejamento da conservação, foi feito um levantamento da população de um local no sul de Sergipe (com uma área total de floresta de cerca de 500 ha) entre abril e outubro de 2008. Procedimentos de transecção linear foram utilizados nos quatro maiores fragmentos e monitoramento adicional incluiu o uso da técnica de playback para a observação de grupos de guigós. A presença de guigós foi confirmada em todos os fragmentos de floresta no local, incluindo um de apenas cinco hectares. Outros dois primatas - Callithrix jacchus e Cebus xanthosternos - também foram registrados no local, mas foram menos abundantes do que o guigó-de-Coimbra-Filho. Um total de $476 \mathrm{~km}$ percorridos proveram 164 avistamentos de primatas, a maioria (104) de Callicebus coimbrai. O tamanho dos grupos desta espécie variou entre dois e cinco indivíduos. A estimativa mais confiável da densidade populacional geral, derivada do conjunto de dados combinados, foi de 12,6 indivíduos por $\mathrm{km}^{2}$, embora a densidade tenha sido muito maior nos fragmentos menores (mais perturbados). A população total de Callicebus coimbrai no local foi estimada em pelo menos 50 indivíduos, que pode representar uma parte considerável da população remanescente da espécie na natureza. Além da sua aparente tolerância à fragmentação de habitat, a densidade de C. coimbrai registrada no local é comparada favoravelmente com a de outras espécies de guigós da Mata Atlântica.
\end{abstract}

Palavras-chave: Callicebus coimbrai, Mata Atlântica, fragmentação de habitat, densidade populacional, conservação. 


\section{Introduction}

Habitat fragmentation has a series of effects on primate populations, and may ultimately lead to local extinction (Bowers and Matter, 1997; Chiarello, 1999, 2000; Peres, 2001; Pardini et al., 2005). While the populations of most species may be affected negatively, some primates are relatively tolerant, and may even increase in density following fragmentation, for example, howlers, Alouatta spp. (Arroyo-Rodríguez and Dias, 2010). Either way, the reliable evaluation of population parameters is essential for the development of effective management strategies (Onderdonk and Chapman, 2000).

First described a decade ago, Coimbra-Filho's titi monkey (Callicebus coimbrai Kobayashi and Langguth, 1999) is found in the Atlantic Forest of Sergipe and northern Bahia (Jerusalinsky et al., 2006; Printes et al., in press), a region devastated by deforestation. While previous estimates of the remaining forest cover in Sergipe referred to values of less than $1 \%$ of the original area (Siqueira and Ribeiro, 2001), a recent study (Santos, 2009) has indicated a proportion closer to $10 \%$, which is similar to the overall average for the biome (Ribeiro et al., 2009). However, this surviving habitat is highly fragmented, and relatively few (25\%) of the remaining tracts of forest are larger than 100 ha (Jerusalinsky et al., 2006). This scenario exacerbates the already limited geographic range of the species and has contributed to its current classification by the IUCN as endangered (Veiga et al., 2008).

Except for more general surveys such as those of Jerusalinsky et al. (2006), Printes (2007) and Sousa et al. (2008), very little is known of the ecological characteristics of $C$. coimbrai. While some ecological data are available for the other Atlantic Forest titis (Müller, 1996; Neri, 1997; Price and Piedade, 2001; Heiduck, 2002; Oliveira et al., 2003; Trevelin et al., 2007), it may be premature to assume that $C$. coimbrai will be similar to these species, especially considering that it is restricted to the northernmost extreme of the genus' distribution in the Atlantic Forest, where the biome is reduced to a relatively narrow coastal strip. However, in the first ecological study of C. coimbrai, Souza-Alves (2010) recorded ecological patterns similar to those of other Atlantic Forest titis.

In the present study, the first detailed data on the population density and other demographic parameters of C. coimbrai were obtained from a site in southern Sergipe. While such data provide only preliminary insights into the ecological characteristics of a species, they can be fundamentally important to evaluate the status of endangered taxa, especially when impacted by habitat fragmentation (Laurance, 1990). The results also provided the first data on local populations of the critically endangered Cebus xanthosternos Wied-Neuwied, 1826.

\section{Material and Methods}

\subsection{Study area}

The Fazenda Trapsa $\left(11^{\circ} 12^{\prime} \mathrm{S}, 37^{\circ} 14^{\prime} \mathrm{W}\right)$ is a privatelyowned rural property in the municipality of Itaporanga d'Ajuda, located in the southern part of the Brazilian state of Sergipe (Figure 1). The forest reserve encompasses eight fragments of Atlantic Forest of various sizes, up to 120 ha, with a total area of approximately 500 ha. Due to its proximity to the coast, the vegetation is best classified as arboreal restinga, which is similar in composition to the inland Atlantic Forest in terms of species composition (Scarano, 2002), but is characterised by vegetation of relatively low stature (canopy of approximately $15 \mathrm{~m}$ ) located on extremely sandy soils. The quality of the habitat varies considerably among fragments, and the smaller patches tend to have more disturbed forest (Chagas, 2009).

The fragments are set within a matrix of abandoned pastures and artificial lakes, including a central reservoir, and also vary with regard to connectivity - in some cases (e.g. fragments 4 and 6), the areas are separated only by a service road (Figure 1). Fragment size was calculated from high resolution $(1: 10,000)$ aerial photographs using ArcGis 9.2. While all of the fragments have experienced some degree of disturbance in the past, there has been no logging or hunting over the past fifteen years (prohibited by the owner and enforced by the foreman), although a large proportion of fragment 2 was affected by a fire in 1997.

Two of the fragments were not included in the present study due to logistic difficulties during the study period (although they are known to contain titi groups due to vocalisations). Of the remaining six fragments, the two smallest (Table 1) were only surveyed qualitatively. A system of straight-line trails was established in each fragment (Figure 1), varying in configuration and length, according to its size and shape (Table 1). The trails were cut with minimum impact, swept clear of debris, and marked at 50-m intervals with forester's tape. These trails were the main, but not the only focus of data collection at the study site.

\subsection{Data collection}

The fragments were surveyed in two main ways. In the smaller fragments ( 5 and 6 ), the presence of titis was investigated using playbacks of the typical territorial duet vocalisation of the genus (Callicebus nigrifrons (Spix, 1823)), played through an MP3-megaphone system developed by Santos Junior (2007). The recording was broadcast at 50-m intervals along the trail system in an attempt to elicit a response from the resident titis. Following a response, the position on the trail system, as well as direction and estimated distance of the vocalisations in relation to the observer were recorded. Further attempts were made to contact the animals and, whenever they came into view, notes were taken on group composition. Playback surveys were conducted once a week only in April, September, and October, 2008.

The larger fragments (1-4) were surveyed using standard line transect procedures (Buckland et al., 2001), in which the trails were walked carefully at a speed of 1.0-1.5 km/ hour in an attempt to locate primates and other nonvolant mammals. Once a mammal was sighted, a standard set of data were collected, including time and location on the trail, the species and number of individuals, the perpendicular 


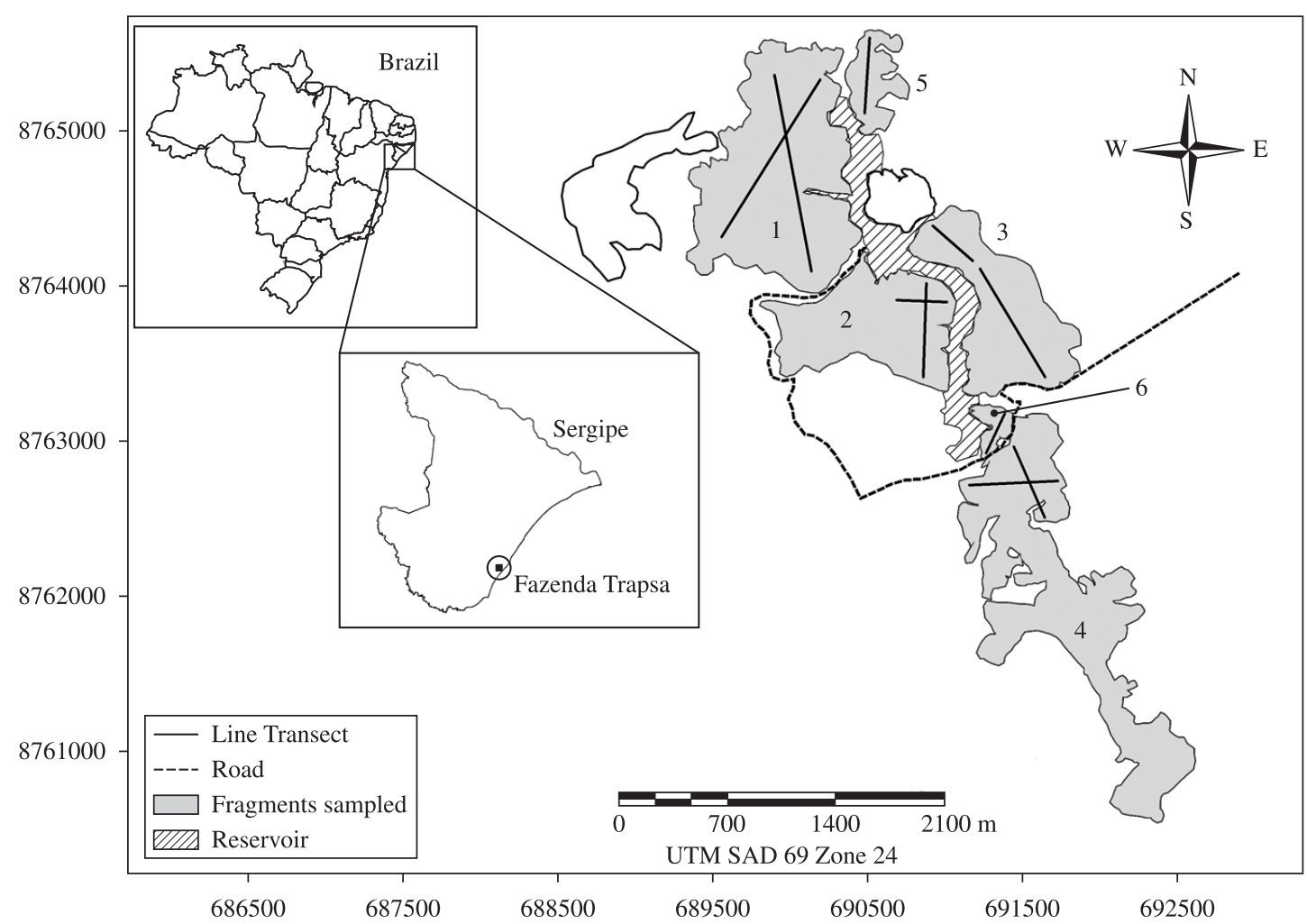

Figure 1. The eight fragments of the forest reserve of the Fazenda Trapsa. The fragments surveyed in the present study are shaded and numbered (see Table 1).

Table 1. Fragment size, trail system (see Figure 1), survey effort and composition of the resident C. coimbrai groups at Fazenda Trapsa in the Brazilian state of Sergipe.

\begin{tabular}{lcccccc}
\hline $\begin{array}{c}\text { Fragment } \\
\text { name/number } \\
\text { (Figure 1) }\end{array}$ & $\begin{array}{c}\text { Size } \\
\left(\mathbf{k m}^{2}\right)\end{array}$ & $\begin{array}{c}\text { Trail } \\
\text { system }(\mathbf{m})\end{array}$ & $\begin{array}{c}\text { Total } \\
\text { transect } \\
\text { walked }(\mathbf{k m})\end{array}$ & $\begin{array}{c}\text { Number } \\
\text { of } \\
\text { groups }\end{array}$ & $\begin{array}{c}\text { Group sizes } \\
\text { (number of } \\
\text { individuals) }\end{array}$ & $\begin{array}{c}\text { Mean } \\
\text { group size } \\
\text { (individuals) }\end{array}$ \\
\hline Alagado/1 & 1.18 & 2460 & 182.0 & 3 & $3,4,5$ & 4.0 \\
Viveiro/2 & 0.62 & 875 & 73.4 & 2 & 5,5 & 5.0 \\
Encosta/3 & 0.61 & 1280 & 135.2 & 3 & $3,4,4$ & 3.7 \\
Bóia/4 & 1.07 & 775 & 85.5 & 4 & $2,2,3,4$ & 2.8 \\
Camboinha/5 & 0.16 & 250 & - & 2 & 3,4 & 3.5 \\
Coroa/6 & 0.05 & 100 & - & 1 & 3 & 3.0 \\
Total & 3.69 & 5740 & 476.1 & 15 & $2-5^{1}$ & 3.6 \\
\hline
\end{tabular}

${ }^{1}$ Range of values.

distance between the animal and the trail. The surveys were conducted on four consecutive days each week between April and October, 2008, with trails being walked between 06:00 AM and 05:00 PM, although data collection was interrupted whenever atmospheric conditions (wind, rain) reduced visibility significantly. The fragments were surveyed on a randomised rotating schedule to ensure even sampling throughout different times of the day.
The survey records for Callicebus coimbrai were analysed using DISTANCE, version 5.0 (Thomas et al., 2006), based on effective strip width. Estimates of group density were based on the detection probability function with the lowest AIC (Akaike's Information Criterion) value, as recommended by Buckland et al. (2001). These values were multiplied by mean group size to provide estimates of population density (number of individuals per $\mathrm{km}^{2}$ ). 
As group size tends to be underestimated in surveys of this type, due to the reduced visibility of animals in this type of procedure, a more reliable value was derived from the group counts accumulated during the study period from playback surveying, non-systematic observations and ecological monitoring activities conducted during the study period (Chagas, 2009; Souza-Alves, 2010). Together with the survey data, sightings were cross-referenced in order to establish the distribution and composition of groups within the fragments. These observations were also used to provide more reliable estimates of Callicebus population density, given the apparent inaccuracies of the transect data (Ferrari et al., 2010). The different estimates were used for comparisons with other studies of personatus group titis.

\section{Results}

\subsection{Playback surveys}

In fragment 6 , responses to the playback resulted in the confirmation of a single group of Callicebus coimbrai, with three members, a breeding pair and a juvenile. Based on responses to playbacks, the slightly larger fragment 5 appears to contain two titi groups, although it was possible to confirm the composition of only one of these. Souza-Alves (2010) and I.P. Fontes (pers. comm.) have nevertheless confirmed the presence of two groups, with three and four members.

\subsection{Group composition}

Observations of titis in the four main fragments revealed group sizes of between two and five individuals (Table 1). It seems likely that most, if not all groups, consisted of an

Table 2. Relative abundance of the three primates species at Fazenda Trapsa in the Brazilian state of Sergipe, according to line transect survey records.

\begin{tabular}{ccrr}
\hline \multirow{2}{*}{ Fragment } & \multicolumn{3}{c}{ Sightings (per 10 km walked) of: } \\
\cline { 2 - 4 } & Callicebus & \multicolumn{1}{c}{ Cebus } & Callithrix \\
\hline 1 & $20(1.1)$ & $26(1.4)$ & $1(0.1)$ \\
2 & $27(3.7)$ & $3(0.4)$ & $3(0.4)$ \\
3 & $33(2.4)$ & $9(0.7)$ & $4(0.3)$ \\
4 & $24(2.8)$ & $3(0.4)$ & $11(1.3)$ \\
Total & $104(2.2)$ & $41(0.9)$ & $19(0.4)$ \\
\hline
\end{tabular}

adult pair and up to three immature individuals. The two remaining groups, in fragment 4 , were adult pairs. The smaller fragments had fewer resident groups, on average, but there seemed to be no clear pattern with regards to group size, except for the presence of slightly smaller groups, on average, in the larger fragments.

\subsection{Line transect surveys}

The $476 \mathrm{~km}$ of transect provided 164 sightings of primates, and a further 15 records of other mammals (six species). The three primates were observed in all four fragments, although only Callicebus coimbrai $(\mathrm{n}=104)$ and Cebus xanthosternos ( $\mathrm{n}=41$ ) were sighted frequently enough to calculate reliable density estimates using sighting functions, according to the criterion of Buckland et al. (2001). However, as only a single capuchin group was present in the study area, only sighting rates are presented for this species, as a measure of its exploration of the different fragments.

Callithrix jacchus (Linnaeus, 1758) was sighted only 19 times, which precludes any reliable estimate of population density from the survey data. The species was only observed regularly in fragment 4 (Table 2), whereas it was sighted only once in fragment 1 - the largest and best-preserved of the four fragments - in $182 \mathrm{~km}$ of transect.

The capuchins showed preference for fragment 1 and, to a lesser extent, fragment 3 . There is a potentially interesting inverse relationship between the sighting rates of Cebus and Callicebus which may reflect interspecific competition, although analysis of this question would require a more specific study. While the capuchins clearly preferred the relatively well-preserved fragment 1 , they regular visited fragment 3, where they were recorded at least once in all six months, and have been observed feeding in the much smaller fragment 5 (J.P. Souza-Alves pers. comm.).

The relatively large number of sightings of Callicebus allowed for a statistically reliable analysis of the survey data using sighting functions (Thomas et al., 2006), although this analysis appeared to overestimate group density considerably in comparison with known parameters (Ferrari et al., 2010). The uniform model with cosine adjustment and an effective strip width of $13.52 \mathrm{~m}$ provided an estimate of group density of 9.2 (95\% confidence interval: 6.2-13.6) per $\mathrm{km}^{2}$, more than double the known value (3.4 groups per $\mathrm{km}^{2}$ ) for the four fragments as a whole (Table 3).

Table 3. Known densities of titis at the Fazenda Trapsa in the Brazilian state of Sergipe.

\begin{tabular}{ccccc}
\hline Fragment & Number of individuals & Area (ha) & ${\text { Groups per } \mathbf{~ k m}^{2}}^{\text {Individuals per km }} \mathbf{~}^{\mathbf{2}}$ \\
\hline 1 & 12 & 118.2 & 2.5 & 10.2 \\
2 & 10 & 61.9 & 3.2 & 16.2 \\
3 & 11 & 61.0 & 4.9 & 18.0 \\
4 & 11 & 107.3 & 3.7 & 10.3 \\
5 & 7 & 15.9 & 12.5 & 43.8 \\
6 & 3 & 5.0 & 20.0 & 60.0 \\
Total & 54 & 369.3 & 4.3 & 14.6 \\
\hline
\end{tabular}




\section{Discussion}

\subsection{Overview}

The results of this first systematic survey of a Callicebus coimbrai population indicate that most basic characteristics of the species are broadly similar to those of other Atlantic Forest titis. All observed groups were either adult pairs, or what appeared to be pairs with their immature offspring, and the maximum size recorded in fifteen groups was five individuals, which is consistent with the strictly monogamous social structure of the genus (Norconk, 2007). Group densities in the four main fragments were consistent with home ranges of between 20 and 40 ha, which are medium values for the personatus group (BiccaMarques and Heymann, in press).

As even the smallest of these fragments is much larger than the largest home range recorded for a personatus group species (48 ha in C. nigrifrons: Neri, 1997), it seems reasonable to conclude that factors other than fragment size may determine group size here. What seems most likely is that the size of a group at a given moment is determined by its recent history of formation, reproduction, and dispersal. As the distances between fragments vary from negligible (i.e. the width of the service road) to no more than $200 \mathrm{~m}$, it seems reasonable to assume that titis are able to disperse relatively freely between fragments, and that isolation does not have a direct influence on the characteristics of the different groups.

Callicebus coimbrai was not only relatively abundant at the Fazenda Trapsa, but was by far the species most frequently sighted during surveys, although titis were relatively much less abundant in the largest, and bestpreserved fragment, in which capuchins were most common. In addition to possible competitive exclusion, involving all three species at different levels of interaction, the role of Cebus as a potential predator (Sampaio and Ferrari, 2005) may also be relevant here.
The Fazenda Trapsa is home to a total population of at least 54 titis. This is not a large population by any standard, especially considering its long-term viability (Reed et al., 2003), but it may nevertheless represent up to $5 \%$ of the total population of the species in the wild (Jerusalinsky et al., 2006) and is likely to play an important role in the conservation of $C$. coimbrai. The data also provide more systematic parameters to assess other $C$. coimbrai populations, depending on variables such as fragment size and the presence of syntopic primates.

\subsection{A comparative perspective}

A number of studies now provide demographic data for the three other Atlantic Forest titis, Callicebus personatus (É. Geoffroy, 1812), C. melanochir Wied-Neuwied, 1820, and $C$. nigrifrons (Tables 4 and 5). When compared with other line transect data, the results from the present study indicate that $C$. coimbrai is relatively abundant at Fazenda Trapsa, compared to the titi populations at sites in southeastern Brazil (Table 4). Even when based on the most conservative estimate of mean group size (derived from sighting data), density at the Fazenda Trapsa is considerably higher than that recorded at other studies.

The estimate of population density derived from the monitoring of groups nevertheless provides a somewhat different picture when compared with similar estimates from other studies (Table 5). In this case, the population density of $C$. coimbrai is intermediate between those of C. nigrifrons and C. melanochir. An overview of both sets of results (Tables 4 and 5) suggests a geographic pattern, characterised by higher densities in the northern species, C. melanochir and C. coimbrai, compared to those from the Brazilian southeast (C. nigrifrons and C. personatus). However, as all the data for the northern species are derived from relatively small fragments of habitat, it is possible that this factor is more relevant than geographic or taxon-specific patterns.

Table 4. Comparison of density estimates for Atlantic Forest titis (Callicebus personatus group) based on line transect surveys.

\begin{tabular}{|c|c|c|c|c|c|}
\hline Species & $\begin{array}{c}\text { Site } \\
\left(\text { area of forest in } \mathrm{km}^{2}\right)^{1}\end{array}$ & $\begin{array}{c}\text { Sighting rate } \\
\text { (per } 10 \mathrm{~km} \\
\text { walked) } \\
\end{array}$ & $\begin{array}{c}\text { Mean } \\
\text { group size } \\
\text { (individuals) } \\
\end{array}$ & $\begin{array}{c}\text { Population } \\
\text { density } \\
\text { (inds./km²) }\end{array}$ & Source $^{2}$ \\
\hline \multirow[t]{3}{*}{ C. nigrifrons } & Viçosa, MG (0.75) & 1.8 & 3.1 & 14.9 & 1 \\
\hline & Serra da Cantareira, SP (79.2) & 1.4 & 2.7 & 11.2 & 2 \\
\hline & São José, SP (2.3) & 0.6 & 1.7 & 3.5 & 3 \\
\hline \multirow[t]{5}{*}{ C. personatus } & ReBio Sooretama, ES (242.5) & 1.7 & 3.0 & 9.5 & 4 \\
\hline & Reserva Florestal Linhares, ES (218.0) & 1.2 & 3.0 & 7.7 & 4 \\
\hline & Putiri, ES (2.1) & 1.0 & 3.0 & 6.4 & 4 \\
\hline & ReBio Augusto Ruschi, ES (40.0) & 0.5 & 3.9 & 5.4 & 5 \\
\hline & M7/317, ES (2.6) & 0.2 & 3.0 & 1.4 & 4 \\
\hline C. coimbrai & Fazenda Trapsa, SE $(3.5)^{3}$ & 2.2 & 2.4 & 22.1 & 6 \\
\hline
\end{tabular}

${ }^{1}$ Brazilian states: ES = Espírito Santo; MG = Minas Gerais; SE = Sergipe; SP = São Paulo; ${ }^{2} 1$ = Oliveira et al. (2003); 2 = Trevelin et al. (2007); 3 = São Bernardo and Galetti (2004); 4 = Chiarello and Melo (2001); 5 = Pinto et al. (1993); 6 = present study; ${ }^{3}$ Total area of the four fragments surveyed by line transect. 
Table 5. Comparison of density estimates for Atlantic Forest titis (Callicebus personatus group) based on ecological monitoring.

\begin{tabular}{|c|c|c|c|c|}
\hline Species & Site (area of forest in $\left.\mathbf{k m}^{2}\right)^{1}$ & $\begin{array}{c}\text { Mean group size } \\
\text { (individuals) }\end{array}$ & $\begin{array}{c}\text { Population density } \\
\text { (inds./km²) }\end{array}$ & Source $^{2}$ \\
\hline \multirow[t]{2}{*}{ C. nigrifrons } & Fazenda Barreiro Rico, SP (32.6) & - & $7-10$ & 1 \\
\hline & Serra do Brigadeiro, MG (132.1) & $2-5$ & 10.3 & 2 \\
\hline \multirow[t]{2}{*}{ C. melanochir } & Fazenda Teimoso, BA (2.4) & - & 17.7 & 1 \\
\hline & Estação Experimental Lemos Maia, BA (10.0) & 4.0 & 17.0 & 3 \\
\hline C. coimbrai & Fazenda Trapsa, SE (3.7) & 3.6 & 14.6 & 4 \\
\hline
\end{tabular}

${ }^{1}$ Brazilian states: BA = Bahia; MG = Minas Gerais; SE = Sergipe; SP = São Paulo; ${ }^{2} 1$ = Pinto et al. (1993); 2 = Cosenza and Melo (1998); 3 = Müller (1996); 4 = present study.

\subsection{Conservation}

What is clear from the present study is that Callicebus coimbrai is a typical Atlantic Forest titi, including a tolerance of habitat fragmentation. While the ability of the species to survive in small fragments may be essential to its survival in the present-day landscape, the potential for dispersal among fragments is a crucial factor (Onderdonk and Chapman, 2000). As Jerusalinsky et al. (2006) have pointed out, the rigid social structure of the titis, in particular the obligatory dispersal of mature offspring, may represent a major problem here. While dispersal may be viable on a local level at the present study site, the much greater distances that separate this population from those on neighbouring properties constitute a major obstacle for metapopulation management. As this situation is typical of the region's fragmented landscape, creating effective corridors is likely to be the greatest challenge for the conservation of C. coimbrai populations in the long term.

Acknowledgements - We are especially grateful to Mr. Ary Ferreira, owner of Fazenda Trapsa, and to José Elias ("Bóia") and João Pedro Souza-Alves for their assistance during the fieldwork. João Pedro and Isadora Fontes also shared unpublished data with us and two anonymous reviewers for their comments on the article. RRDC received a graduate stipend from the Deutscher Akademischer Austausch Dienst (DAAD) and SFF research grants from $\mathrm{CNPq}$ (processes no. 302747/2008-7 and 476064/2008-2).

\section{References}

ARROYO-RODRÍGUEZ, V. and DIAS, PAB., 2010. Effects of habitat fragmentation and disturbance on howler monkeys: a review. American Journal of Primatology, vol. 72, p. 1-16. PMid:19852004. http://dx.doi.org/10.1002/ajp.20753

BICCA-MARQUES, JC. and HEYMANN, EW., in press. Ecology and behaviour of titi monkeys (genus Callicebus). In VEIGA, LM., BARNETT, AA., FERRARI, SF. and NORCONK, MA. (Es.), Evolutionary biology and conservation of titis, sakis, and uacaris, Cambridge. Cambridge: University Press.

BOWERS, MA. and MATTER, SF., 1997. Landscape Ecology of Mammals: Relationship between density and patch size. Journal of Mammalogy, vol. 78, p. 999-1013. http://dx.doi. org/10.2307/1383044
BUCKLAND, ST., ANDERSON, DR., BURNHAM, KP. and LAAKE, JL., 2001. Distance sampling: estimating abundance of biological populations. London: Chapman and Hall.

CHAGAS, RRD., 2009. Levantamentos das populações de Callicebus coimbrai (Kobayashi \& Langguth, 1999) em fragmentos de Mata Atlântica no sul do Estado de Sergipe, Brasil. São Cristóvão: Universidade Federal de Sergipe. 64 p. Dissertação de Mestrado em Desenvolvimento e Meio Ambiente.

CHIARELLO, AG., 1999. Effects of fragmentation of the Atlantic forest on mammal communities in southeastern Brazil. Biological Conservation, vol. 87, p. 71-82.

-, 2000. Density and population size of mammals in remnants of Brazilian Atlantic Forest. Biological Conservation, vol. 14, p. 1649-1657. http://dx.doi.org/10.1111/j.1523-1739.2000.99071.x

CHIARELLO, AG. and MELO, FR., 2001. Primate population densities and sizes in Atlantic forest remnants of northern Espírito Santo, Brazil. International Journal of Primatology, vol. 22, no. 3, p. 379-396. doi:10.1023/A:1010751527749

COSENZA, BAP. and MELO, FR., 1998. Primates of the Serra do Brigadeiro State Park, Minas Gerais, Brazil. Neotropical Primates, vol. 6, p. 18-20.

FERRARI, SF., CHAGAS, RRD. and SOUZA-ALVES, JP., 2010. Line transect surveying of arboreal monkeys: problems of group size and spread in a highly fragmented landscape. American Journal of Primatology, vol. 72, p. 1100-1107. PMid:20683881. http://dx.doi.org/10.1002/ajp.20873

HEIDUCK, S., 2002. The use of disturbed and undisturbed forest by masked titi monkey Callicebus personatus melanochir is proportional to food availability. Oryx, vol. 36, p. 133-139. http://dx.doi.org/10.1017/S0030605302000200

JERUSALINSKY, L., OLIVEIRA, MM., PEREIRA, RF., SANTANA, V., BASTOS, PCR. and FERRARI, SF., 2006. Preliminary evaluation of the conservation status of Callicebus coimbrai (Kobayashi \& Langguth, 1999) in the Brazilian state of Sergipe. Primate Conservation, vol. 21, p. 25-32. http://dx.doi. org/10.1896/0898-6207.21.1.25

KOBAYASHI, S. and LANGGUTH, AB., 1999. A new species of titi monkey, Callicebus Thomas, from north-eastern Brazil (Primates, Cebidae). Revista Brasileira de Zoologia, vol. 16, p. 531-551. http://dx.doi.org/10.1590/S0101-81751999000200018 
LAURANCE, WF., 1990. Comparative responses of five arboreal marsupials to tropical forest fragmentation. Journal of Mammalogy, vol. 71, p. 641-653. http://dx.doi.org/10.2307/1381805

MÜLLER, KH, 1996. Diet and feeding ecology of masked titis (Callicebus personatus). In NORCONK, M., ROSENBERGER, AL. and GARBER, P. (Eds.). Adaptive radiations of Neotropical primates. New York: Plenum Press. p. 383-401

NERI, FM., 1997. Manejo de Callicebus personatus (Geoffroy, 1812) resgatados: uma tentativa de translocação e estudos ecológicos de um grupo silvestre na Reserva Particular do Patrimônio Natural Galheiro - Minas Gerais. Belo Horizonte: Universidade Federal de Minas Gerais. Dissertação de Mestrado em Ecologia, Conservação e Manejo da Vida Silvestre.

NORCONK, MA., 2007. Sakis, uakaris, and titi monkeys: behavioral diversity in a radiation of seed predators, pp. 123-138. In CAMPBELL, CJ., FUENTES, A., MACKINNON, KC., PANGER, M. and BEARDER, SK. (Eds.). Primates in Perspective. Oxford: Oxford University Press.

OLIVEIRA, RCR., COELHO, AS. and MELO, FR., 2003. Estimativa de densidade e tamanho populacional de sauá (Callicebus nigrifrons) em um fragmento de mata em Regeneração, Viçosa, Minas Gerais, Brasil. Neotropical Primates, vol. 11, p. 91-93.

ONDERDONK, AD. and CHAPMAN, CA., 2000. Coping with forest fragmentation: the primates of Kibale national park, Uganda. International Journal of Primatology, vol. 21, no. 4, p. 587-611. http://dx.doi.org/10.1023/A:1005509119693

PARDINI, R., De SOUZA, SM., BRAGA-NETO, R. and METZER, JP., 2005. The role of forest structure, fragment size and corridors in maintaining small mammal abundance and diversity in an Atlantic forest landscape. Biological Conservation, vol. 124, p. 253-266. http://dx.doi.org/10.1016/j.biocon.2005.01.033

PERES, CA., 2001. Synergistic effects of subsistence hunting and habitat fragmentation on Amazonian forest vertebrates. Conservation Biology, vol. 15, p. 1490-1505. http://dx.doi. org/10.1046/j.1523-1739.2001.01089.x

PINTO, LPS., COSTA, CMR., STRIER, KB. and FONSECA, GAB., 1993. Habitat, density and group size of primates in a Brazilian tropical forest. Folia Primatologica, vol. 61, p. 135-143.

PRICE, EC. and PIEDADE, HM., 2001. Ranging behavior and intraspecific relationships of masked titi monkeys (Callicebus personatus personatus). American Journal of Primatology, vol. 53, p. 87-92. http://dx.doi.org/10.1002/1098-2345(200102)53:2<87::AIDAJP4>3.0.CO;2-P

PRINTES, RC., 2007. Avaliação taxonômica, distribuição e status do guigó-da-caatinga (Callicebus barbarabrownae Hershkovitz, 1990). Belo Horizonte: Universidade Federal de Minas Gerais. 156 p. Tese de Doutorado.

PRINTES, RC., JERUSALINSKY, L., SOUSA, MC, RODRIGUES, LRR. and HIRSCH, A., in press. Zoogeography, genetic variation and conservation of the Callicebus personatus group. In VEIGA, LM., BARNETT, AA., FERRARI, SF. and NORCONK, MA. (Eds.). Evolutionary biology and conservation of titis, sakis, and uacaris. Cambridge: Cambridge University Press.

REED, DH., O'GRADY, JJ., BROOK, BW., BALLOU, JD. and FRANKHAM, R., 2003. Estimates of minimum viable population sizes for vertebrates and factors influencing those estimates. Biological Conservation, vol. 113, p. 23-34. http:// dx.doi.org/10.1016/S0006-3207(02)00346-4

RIBEIRO, MC., METZGER, JP., MARTENSEN, AC., PONZONI, FJ. and HIROTA, MM., 2009. The Brazilian Atlantic Forest: How much is left, and how is the remaining forest distributed? Implications for conservation. Biological Conservation, vol. 142, p. 1141-1153.

SANTOS, ALC., 2009. Diagnóstico dos fragmentos de Mata Atlântica de Sergipe através de sensoriamento remoto. São Cristóvão: Universidade Federal de Sergipe. 74 p. Dissertação de Mestrado em Desenvolvimento e Meio Ambiente.

SANTOS JUNIOR, EM., 2007. Observações preliminares sobre a ecologia comportamental do Callicebus coimbrai na Mata Atlântica de Sergipe. São Cristóvão: Universidade Federal de Sergipe. Monografia de Graduação.

SÃO BERNARDO, CS. and GALETTI, M., 2004. Densidade e tamanho populacional de primatas em um fragmento florestal no sudeste do Brasil. Revista Brasileira de Zoologia, vol. 21, no. 4 , p. $827-832$.

SAMPAIO, DT. and FERRARI, SF., 2005. Predation of an infant titi monkey (Callicebus moloch) by a tufted capuchin (Cebus apella). Folia Primatologica, vol. 76, p. 113-115 PMid:15775682. http://dx.doi.org/10.1159/000083617

SCARANO, FR., 2002. Structure, function and floristic relationships of plant communities in stressful habitats marginal to the Brazilian Atlantic rain forest. Annals of Botany, vol. 90, p. 517-524. PMid:12324276. http://dx.doi.org/10.1093/aob/mcf189

SIQUEIRA, ER. and RIBEIRO, FE., 2001. A Mata Atlântica de Sergipe. Aracaju: Embrapa Tabuleiros Costeiros.

SOUSA, MC., SANTOS, SS. and VALENTE, MCM., 2008. Distribuição e variação na pelagem de Callicebus coimbrai (Primates - Pitheciidae) nos estados de Sergipe e Bahia, Brasil. Neotropical Primates, vol. 15, p. 54-59. http://dx.doi.org/10.1896/044.015.0208

SOUZA-ALVES, JP., 2010. Ecologia alimentar de um grupo de Guigó-de-Coimbra-Filho (Callicebus coimbrai Kobayashi \& Langguth, 1999): perspectivas para a conservação da espécie na paisagem fragmentada do sul de Sergipe. São Cristóvão: Universidade Federal de Sergipe. Dissertação de Mestrado em Desenvolvimento e Meio Ambiente.

THOMAS, L., LAAKE, JL., STRINDBERG, S., MARQUES, FFC., BUCKLAND, ST., BORCHERS, DL., ANDERSON, DR., BURNHAM, KP., HEDLEY, SL., POLLARD, JH., BISHOP, JRB. and MARQUES, TA., 2006. Distance 5.0. Release " $x$ "1. Research Unit for Wildlife Population Assessment. St. Andrews: University of St. Andrews. Available from: <http://www.nuwpa. st-and.ac.uk/distance>.

TREVELIN, LC., PORT-CARVALHO, M. and MORELL, E., 2007. Abundance, habitat use and diet of Callicebus nigrifrons Spix (Primates, Pitheciidae) in Cantareira State Park, São Paulo, Brazil. Revista Brasileira de Zoologia, vol. 24, p. 1071-1077.

VEIGA, LM., SOUSA, MC., JERUSALINSKY, L., FERRARI, SF., DE OLIVEIRA, MM., SANTOS, SSD., VALENTE, MCM. and PRINTES, RC., 2008. Callicebus coimbrai. In IUCN (Ed.). IUCN Red List of Threatened Species. Available from: <http:// www.iucnredlist.org/details/39954/0>. 
